\title{
Využívání otevřených vzdělávacích zdrojů studenty environmentálních oborů v České republice
}

\author{
Eduard Petiška
}

Envigogika 13 (1) - Recenzované články / Reviewed Papers

Publikováno /Published 18. 1. 2018

DOI: $10.14712 / 18023061.548$

\begin{abstract}
Abstrakt
Otevřené vzdělávací zdroje (OER) jsou důležitou inovací ve vzdělávacích technologiích. Jejich správné využívání může mít řadu benefitů pro vysokoškolské vzdělávání $\mathrm{i} v$ oblasti environmentálního vzdělávání. Naopak, špatná práce s těmito zdroji může mít negativní dopady na znalosti studentů. Doposud nebylo zřejmé, jaké OER čeští studenti užívají, jak často a k čemu je využívají, a zda jsou schopni určit kritéria kvality. Na základě dosavadních zjištění jsme vypracovali metodu a na jejím základě realizovali výzkum formou dotazníkového šetření. U jednotlivých OER jsme přitom zkoumali a) frekvenci využívání, b) účely využívání a c) subjektivní hodnocení kvality. Dotazníky byly rozdány v rámci environmentálních kurzů na pěti vysokých školách $v$ ČR a celkem bylo vyhodnoceno 233 dotazníků. Ukázalo se, že většina studentů využívá OER často, zejm. Wikipedii, a to jak její českou, tak anglickou verzi, ačkoliv řada z nich má zkušenosti i s úložištěm nelegálních materiálů. Zdroje využívají zejména jako doplněk a sekundární zdroj, případně rozcestník k dalším zdrojům či k přípravě na zkoušky nebo psaní atestačních prací. Jako kvalitní zdroj hodnotí zejména Wikipedii. Většina studentů byla zároveň schopna určit alespoň některá kritéria, podle nichž posuzují kvalitu zdroje.
\end{abstract}

\section{Klíčová slova}

Otevřené vzdělávací zdroje; vysoké školství; environmentální obory

\begin{abstract}
Open educational resources are important innovations in educational technologies. Their appropriate use can have a number of benefits for both higher education and environmental disciplines. Conversely, poor work when using these resources can have a negative impact on students' knowledge. It is currently unclear which OER students refer to, how often and for what purposes they use them, and whether they are able to determine any criteria of quality. On the basis of previous findings, we developed a method and conducted research in the form of a questionnaire-based survey. We investigated a) the frequency of use b) the purposes of use c) subjective quality assessment. Questionnaires were distributed among students of environmental courses at five universities in the Czech Republic; 233 questionnaires were evaluated. The results showed that most students use OER frequently, especially Wikipedia, both its Czech and English versions, although many of the students also have some experience with the storage of illegal materials. Resources are used in particular as a supplementary and secondary resource, as a signpost to other resources, to prepare for a test, or when writing attestation work. As a quality resource, students value Wikipedia in particular. Most students were also able to identify at least some criteria to which they refer when assessing the quality of a resource.
\end{abstract}

\section{Key words}

Open Educational Resources; Higher education; Environmental disciplines 
Otevřené vzdělávací zdroje (anglicky Open Educational Resources - OER) jsou definovány jako: „,Výukové, vzdělávací a výzkumné zdroje, které jsou ve veřejném vlastnictví, nebo byly vydány pod takovou licencí duševního vlastnictví, která umožňuje jejich volné použití a opětovné úpravy ostatními uživateli. Otevřené vzdělávací zdroje zahrnují veškeré kurzy, studijní materiály, moduly, učebnice, streamovací videa, testy, software a jakékoli jiné nástroje, materiály nebo techniky používané na podporu př́stupu ke znalostem." (Hewlett Foundation, 2015). Tyto zdroje tedy umožňují volně využívat, vytvářet, upravovat i šírit studijní materiály (Wiley, 2014). Představují značnou výzvu pro vydavatelskou kulturu a vzdělávací systémy. Při současném tempu vědeckého poznání se poznatky mohou stát zastaralými již v průběhu publikačního procesu a OER tak mohou představovat alternativu či dopIněk klasických učebních textů. Aktuální studijní materiály jsou důležité zejména ve vysokoškolském vzdělávání. Většina dotazovaných učitelů v USA uvádí, že využívají OER častěji než klasické zdroje (TES Global, 2016). Jsou také výrazně levnější alternativou ke klasickým učebnicím (Hilton, 2016). S využíváním těchto zdrojů je sice spojeno množství potenciálních výhod, ale i problémů. Pokud studenti využívají nekvalitní zdroje nebo si osvojí špatnou praxi, může to mít negativní dopady nejen na jejich studium ale - díky osvojeným vzorcům práce s informacemi - i na pozdější výkon povolání. Tento fenomén si proto zaslouží značnou pozornost. Zkoumání jejich využívání přesto není přiliš časté (Hu a kol., 2015). Ukazuje se, že aplikace otevřených vzdělávacích zdrojů může být zároveň vhodná i v oblasti životního prostředí a environmentálních studií.

\section{OER v kontextu environmentálních studií}

Oblast informační technologie a otevřený př́stup k poznatkům je vymezena jako důležitý předpoklad jak pro zlepšování životního prostředí, tak pro naplňování Cílů udržitelného rozvoje (SDGs) (Tjoa \& Tjoa, 2016). Zájem o otevřenost je v oblasti životního prostředí založen na kultuře otevřenosti formulované Aarhuskou úmluvou, která zaručuje univerzální právo na prístup $\mathrm{k}$ informacím, které se týkají životního prostředí; principy otevřeného prostředí jsou pak zvláště relevantní pro environmentální studia, v nichž dochází ke komplexnímu propojení vědních oborů (Dlouhá a kol., 2015). OER mohou také doplnit klasické učební texty a být tak vhodnou pomůckou při vzdělávání k udržitelnému rozvoji (Roeder a kol., 2017). Mưžeme definovat tři hlavní důvody pro využívání OER v environmentálních studiích:

- Snadnost aktualizace. Vzhledem ke značnému nárůstu zkoumání různých aspektů životního prostředí dochází také k rychlému zastarávání dřivějších poznatků. Je proto kladen požadavek na častou aktualizaci zdrojů. Obměna tištěných zdrojů je oproti elektronickým časově, materiálně i finančně náročná.

- Transdisciplinarita. Environmentální problémy jsou ze své podstaty transdisciplinární povahy, z tohoto důvodu je vhodné, aby materiály byly vytvářeny také kolaborativně (bud' př́mo psány či recenzovány kolektivem odborníků). Digitální prostředí navíc poskytuje specifické výhody pro snazší orientaci v různých tématech (formou odkazů, využívání volně dostupných materiálů atd.).

- Přístupnost. Zpřistupňování informací různým skupinám aktérům je velkou výzvou právě v oblasti životního prostředí. Otevřené platformy jsou pro to ideálním nástrojem. 


\section{OER v České republice}

V USA a západní Evropě se termín OER používá již běžně (Belikov \& Bodily, 2016; Bone, Elizabeth \& McNichol, 2014; Bliss \& Smith, 2017). V českém prostředí se s ním však zatím setkáváme relativně málo: "Z analýzy vědecko-výzkumných a veřejně dostupných informačních zdrojů vyplývá, že termín OER používá jen malá část českých vysokých škol (N $=8$ ), což představuje zhruba čtvrtinu všech veřejných a státních vysokých škol v České republice." (Kapitulčinová a kol., 2015). Nezájem vzdělávacích institucí o OER pak může být príčinou rozdílné kvality těchto zdrojů. To platí u zdrojů zaměřených na životní prostředí, výsledky výzkumu ukázaly, že OER zaměřené na životní prostředí v českém jazyce mají značně odlišnou kvalitu (Dlouhá a kol., 2015).

Je potřeba ale také zmínit, že v poslední době dochází k pokrokům v podobě projektů, koncepcí a aktivit směřujících $\mathrm{k}$ otevřenému vzdělávání. Vláda schválila strategii digitálního vzdělávání do roku 2020, v tomto dokumentu je zmiňována jak podpora otevřeného vzdělávání, tak OER. Vznikla Aliance pro otevřené vzdělávání, která sdružuje aktéry činné $v$ této oblasti. Byly také realizovány výše zmiňované výzkumy. I přes tyto dílčí pokroky je ale možné konstatovat, že zájem většiny vzdělávacích institucí o tuto oblast je poměrně slabý. To reflektuje fakt, že zatím nebyl proveden výzkum zaměřený na využívání těchto zdrojů ve vysokoškolském prostředí mezi pedagogy ani studenty.

\section{Problém kvality}

Rozvoj internetu a zapojení široké veřejnosti do vytváření obsahu podnítilo pocity informační přehlcenosti, nárůst dezinformací a další paradoxy a patologie (Bawden, 2009). Mnozí badatelé si proto začali klást otázky, podle čeho se uživatelé rozhodují, které informace jsou kvalitní. Byly proto definovány jednotlivé aspekty kvality (Kandari a kol., 2011). Posuzování kvality je důležité při využívání OER, protože jejich kvalita značně kolísá a je tak potřeba zvláštní obezřetnosti při jejich použivání. Proto je problematika kvality zkoumána i ve výzkumech zaměřených na využívání a vnímání těchto zdrojů (Hilton, 2016). Náleží ale také často do výzkumného proudu mimo oblast OER, vzhledem $\mathrm{k}$ tomu, že řada studií zabývajících se posuzováním kvality informací, které studenti nachází na internetu, termín OER nezmiňuje a teoretický základ jim poskytuje informační věda a př́buzné disciplíny.

Ukázalo se, že pro studenty je internet primárním zdrojem informací, přičemž ale mnozí postrádají kritické myšlení při jeho využívání (Graham, 2003). Kleinová (2002) provedla výzkum zaměřený na posuzování kvality informací na internetu vysokoškolskými studenty ekonomického zaměření. Studenti uznávali, že jim internet umožňuje snadný přístup $k$ patřičnému množství relevantních informací. Nicméně uváděli problémy s přesností, objektivitou a zabezpečením př́stupu k informacím na internetu. Zároveň se ukázalo, že délka studia má vliv na posuzování informací, vzhledem $\mathrm{k}$ tomu, že magisterští studenti byli $\mathrm{k}$ informacím na internetu skeptičtější. Výzkum ale bral kvalitu informačního prostředí jako celek a neumožňoval hodnotit jednotlivé zdroje zvlášt́. Není také zřejmé, zda by studenti dokázali sami určit indikátory kvality, podle nichž se rozhodují. Rovněž se ukazuje, že vnímání kvality informací na internetu má dopad na jejich využívání (Pow \& Li, 2015). Výsledky jiného výzkumu (Burton, 2002), který byl také proveden mezi vysokoškolskými studenty, poukázaly na fakt, že důležitým kritériem při využívání zdrojů je zejména snadnost vyhledání. Studenti jdou cestou nejmenšího odporu, když mají vyhledat potřebné informace, a používají zažité způsoby vyhledávání před nově naučenými metodami (Warwick, 2009). Studenti také preferují využívání volně dostupných informací na internetu před specializovanými databázemi, v nichž je vyhledávání často obtížnější (Biddix a kol., 2011). Výsledky dalšího výzkumu mezi studenty argumentují pro potřebu zvyšovat znalost internetového prostředí, která se pozitivně odrazí 
při jeho využívání (Wei \& Zhang, 2008). Výzkum realizovaný v USA na velkém vzorku studentů (7804 respondentů) poukázal na skutečnost, že studenti, i když se běžně pohybují v digitálním prostředí, mají problém rozeznat kvalitní informace. Více než $80 \%$ studentů například věří, že reklamní sdělení je oficiální novinová zpráva. Mají také problémy s hodnocením zpráv na twitteru i u dalších sdělení (Wineburg a kol., 2016).

Problematika kvality zdrojů je zvláště relevantní nejen pro OER, ale také pro environmentální studia. $V$ oblasti životního prostředí jsme často konfrontováni $s$ řadou dezinformací, dezinterpretací a nedorozumění, které jsou šířeny nevědomě i záměrně. Vědecká témata jsou často směšována s aktivismem a jsou politizována. O jistém zmatení pojmu svědčí např. užívání termínu ekologie jako synonyma pro ochranu prostředí či pro environmentální aktivismus ve společensky citlivých kauzách (Novotný, 2010). Setkáváme se ale také s řadou zcela mylných informací a hoaxů. Populární je např. přesvědčení o škodlivosti geneticky modifikovaných organismů (Eldred, 2009); navzdory vědeckým studiím si řada lidí myslí, že mají závažné dopady na lidské zdraví. Některé informace mají ráz konspiračního charakteru či bludu, jako je např. tvrzení o ",chemtrails", které ríká, že práškovací letadla do atmosféry záměrně roznášejí látky poškozující lidské zdraví (Bessi, 2015). Se značným počtem dezinformací se setkáváme také $v$ problematice globální změny klimatu, zde jsou zavádějící informace často využivány různými zájmovými skupinami. Způsobem, jak se jim bránit, může být např. informování veřejnosti o jejich záměrném šiření (van der Linden, 2017).

Je patrné se, že ani studenti nejsou proti různým dezinformacím imunní a často je širrí (Chen et al., 2015). Výsledky výzkumu mezi studenty v Austrálii poukázaly na špatné chápání problematiky ozonové vrstvy (Cordero, 2000). Pokud jsou studenti ale vedeni ke studiu dezinformací např. $v$ oblasti klimatologie, může to naopak podpořit jejich kritické myšlení a porozumění vědecké práci (Bedford, 2010). Na základě dosavadních zjištění můžeme proto konstatovat, že problematika kvality informací je významná jak pro environmentální studia, tak pro otevřené prostředí internetu a chování studentů při jeho využívání, přičemž dosud není zcela zřejmé, jak studenti hodnotí kvalitu zdrojů, které využívají a jaká kritéria při tom využívají.

\section{Cíle výzkumu}

Cílem výzkumu bylo zjistit, jaký je stav využívání OER studenty environmentálních oborů v ČR. Za tímto účelem jsme formulovali výzkumnou otázku: "Jaké jsou charakteristiky využívání OER studenty environmentálních oborů?" Zároveň jsme formulovali jednotlivé výzkumné podotázky:

- Jaké OER studenti environmentálních oborů využívají?

- Jak často studenti environmentálních oborů OER využívají?

- Za jakým účelem studenti environmentálních oborů OER využívají?

- Jak studenti environmentálních oborů hodnotí kvalitu OER?

- Jaká kritéria kvality studenti environmentálních oborů při hodnocení kvality OER používají?

\section{Výzkumná metoda}

Výzkum navazuje na studii, která mapovala výskyt environmentálních OER, které jsou k dispozici v českém jazyce (Dlouhá a kol., 2015). $V$ ní byl proveden výzkum OER zaměřených na oblast životního prostředí. Zdroje byly rozčleněny do několika kategorií podle stupně 
otevřenosti a ohodnoceny, zda splňují požadavky kvalitního zdroje (viz Př́loha 1 ). Z těchto zdrojů jsme vybrali př́klady jednotlivých kategorií a díky předvýzkumu jsme dále zúžili výběr na ty zdroje, které studenti pravděpodobně využívají. Tyto zdroje jsme poté zahrnuli do dotazníku, zároveň nechali prostor na dopsání dalších zdrojů, pokud je studenti využívají. U každého zdroje jsme zkoumali:

- a) frekvenci využívání;

- b) účely využívání;

- c) hodnocení kvality.

Za účelem získání poznání toho, zda jsou studenti kvalitu opravdu hodnotit podle určitých kritérií, jsme jim položili následující otevřenou otázku:

- „,Můžeš napsat v bodech 3 hlavní kritéria, podle kterých posuzuješ kvalitu OER? Každé kritérium napiš na jeden řádek, pokud nevíš, nechej prázdný rádek."

Na základě odpovědí na tuto otázku jsme následně sestavili jednotlivé kategorie kritérí. Dotazník (viz Příloha 2) jsme následně otestovali v rámci předvýzkumu.

Dotazníkové šetření bylo realizováno v akademickém roce 2016/2017 na českých vysokých školách. Do výzkumu byli zahrnuti studenti environmentálních kurzů (tj. oboru Ekologie a ochrana prostředí a př́buzných oborů) bakalářských a magisterských oborů na Jihočeské univerzitě, Masarykově univerzitě, Ostravské univerzitě, Univerzitě Karlově a Univerzitě Palackého. Studentům byly rozdány dotazníky s žádostí o jejich vyplnění. Výzkumu se zúčastnilo 233 respondentů. Účast byla anonymní a dobrovolná. Odpovědi jsme nakódovali a statisticky vyhodnotili pomocí kontingenční tabulky $v$ excelu.

Tabulka znázorňující výzkumný vzorek respondentů

\begin{tabular}{|l|l|l|}
\hline & Počet & Procenta \\
\hline Muži & 91 & 39 \\
\hline Ženy & 142 & 61 \\
\hline Bakalářš́ studenti & 110 & 48 \\
\hline Magisterští studenti & 120 & 52 \\
\hline Počet respondentů z Masarykovy univerzity & 31 & 13 \\
\hline Počet respondentů z Palackého univerzity & 33 & 14 \\
\hline Počet respondentů z Jihočeské univerzity & 89 & 38 \\
\hline Počet respondentů z Univerzity Karlovy & 30 & 13 \\
\hline Počet respondentů z Ostravské univerzity & 50 & 21 \\
\hline
\end{tabular}




\section{Výsledky a diskuze ${ }^{1}$}

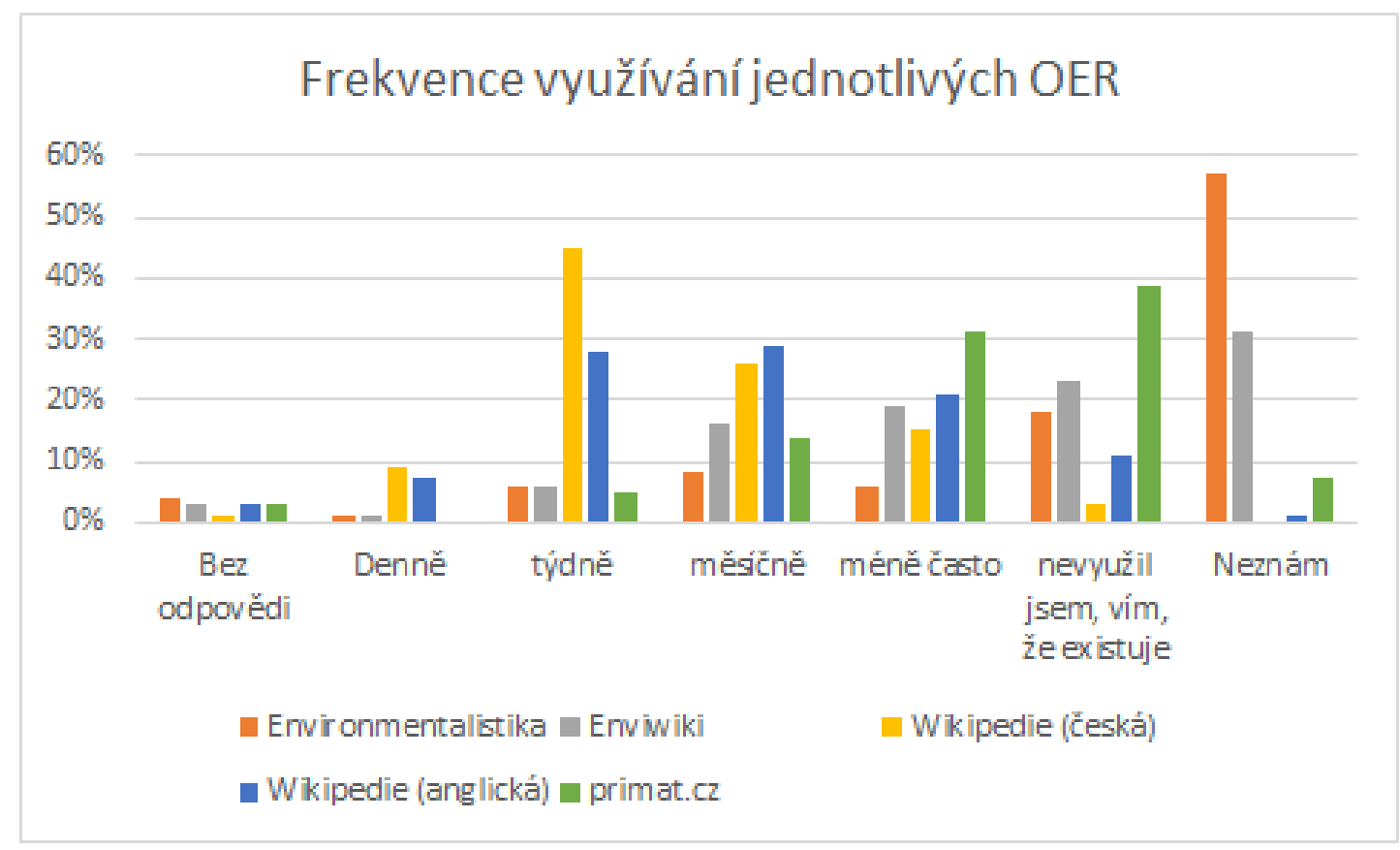

Obrázek 1. Graf znázorňující využívání frekvenci využívání OER pro oblast životního prostředí

Z grafu je patrné, že zdaleka nejpoužívanějším zdrojem je mezi studenty Wikipedie, a to jak její česká, tak anglická verze. Další zdroje používají o poznání méně častěji.

Kromě výše uvedených zdrojů někteří studenti také uvedli, že využívají zdroje, které v tabulce nebyly uvedeny. Jednalo se ale o pouze o několik jednotlivců (celkem 13 respondentů), ostatní nenapsali žádný další zdroj, který ke studiu využívají. Jako další zdroje respondenti uvedli následující: „I fucking love science“; „videa“; „ekospace.cz“; „č. stat. úřad“; „zelené zprávy“; "ministerstvo životního prostředí"; "Science Direct“; „Web of Science“; "Wiley Library“; "Scholar Google“; "geology.cz (slovník)“; „enviweb.cz“; „AOPK“; „Facebook“; "Geology page“; „Povodí Odry“; "Cenia“; "Nature.cz"; „Vítejte na Zemi“.

\footnotetext{
${ }^{1}$ Detailní výsledky se znázorněnými počty procent jsou uvedeny dále (viz Příloha 3).
} 


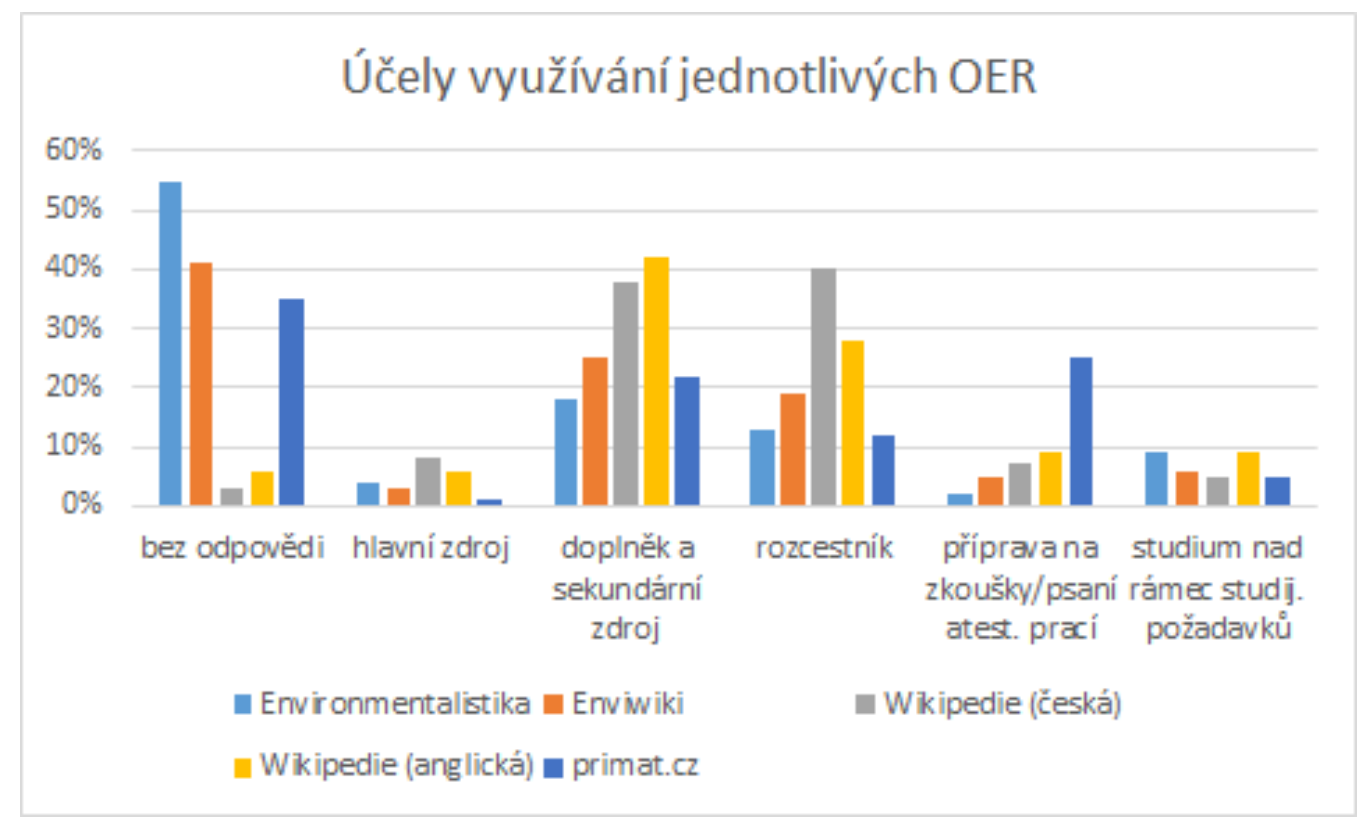

Obrázek 2. Graf znázorňující účely využívání OER pro oblast životního prostředí

Ukazuje se, že studenti na OER nespoléhají jako na hlavní zdroj, spíše je využívají jako doplněk a sekundární zdroj, popř. jako rozcestník k dalším zdrojům.

Vidíme, že celá čtvrtina studentů využívá zdroj primat.cz, na němž se vyskytují informace rozdílné kvality a jež se vyznačuje nekorektním sdílením, protože jsou na něm umístěné takové nelegální materiály jako např. otázky $k$ testům atd. (viz Př́loha 1 ). $Z$ odpovědí je patrné, že tento zdroj studenti nevyužívají pouze jako doplněk a rozcestník, ale také $k$ př́pravě na zkoušky/psaní atestačních prací (ve větší míre než ostatní zdroje). Můžeme tedy usuzovat, že si zde osvojují špatnou praxi a nelegální postupy, které zároveň aplikují při studiu.

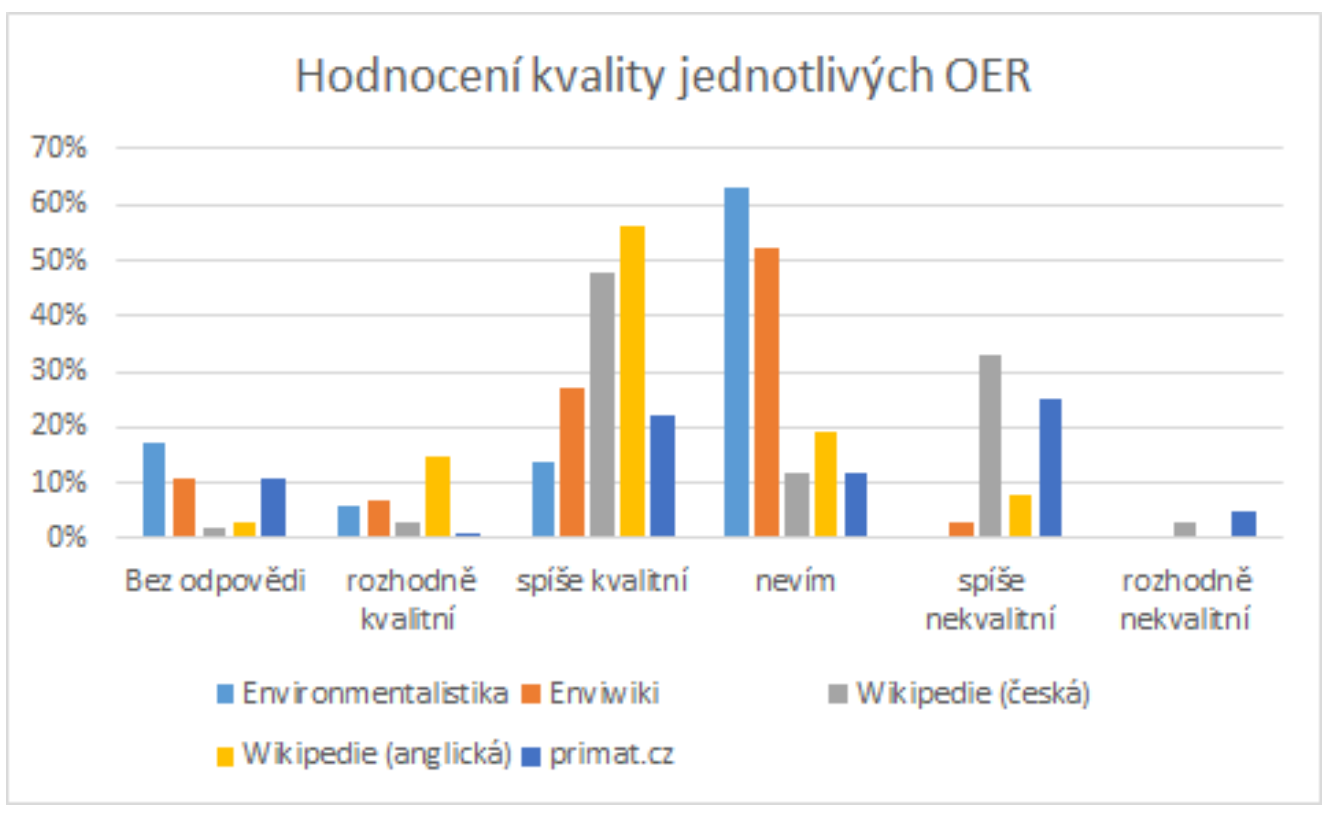

Obrázek 3. Graf znázorňující hodnocení kvality OER pro oblast životního prostredí 
Subjektivní hodnocení kvality nám ukazuje, že studenti vnímají jako nejkvalitnější zdroj Wikipedii, zejména její anglickou verzi. Otázky kolem kvality Wikipedie vzbuzují časté diskuze. I když se ukázalo, že některé články mohou být kvalitnější než např. Encyclopædia Britannica (Giles, 2005), kvalita jednotlivých hesel značně varíruje. To platí především u její české verze, kterou pravidelně opravuje či upravuje pouze pár editorů. Posouzení kvality článků v oblasti životního prostředí na Wikipedii by však bylo námětem na samostatný výzkum.

Portál primat.cz označují studenti bud' jako spíše kvalitní, anebo spíše nekvalitní. Nabízí se vysvětlení, že to může být právě důsledek kvality materiálu, se kterým se na stránkách portálu setkali, případně tím, do jaké míry jim pomohl splnit studijní požadavky (at́ již standardní cestou, anebo nelegálně).

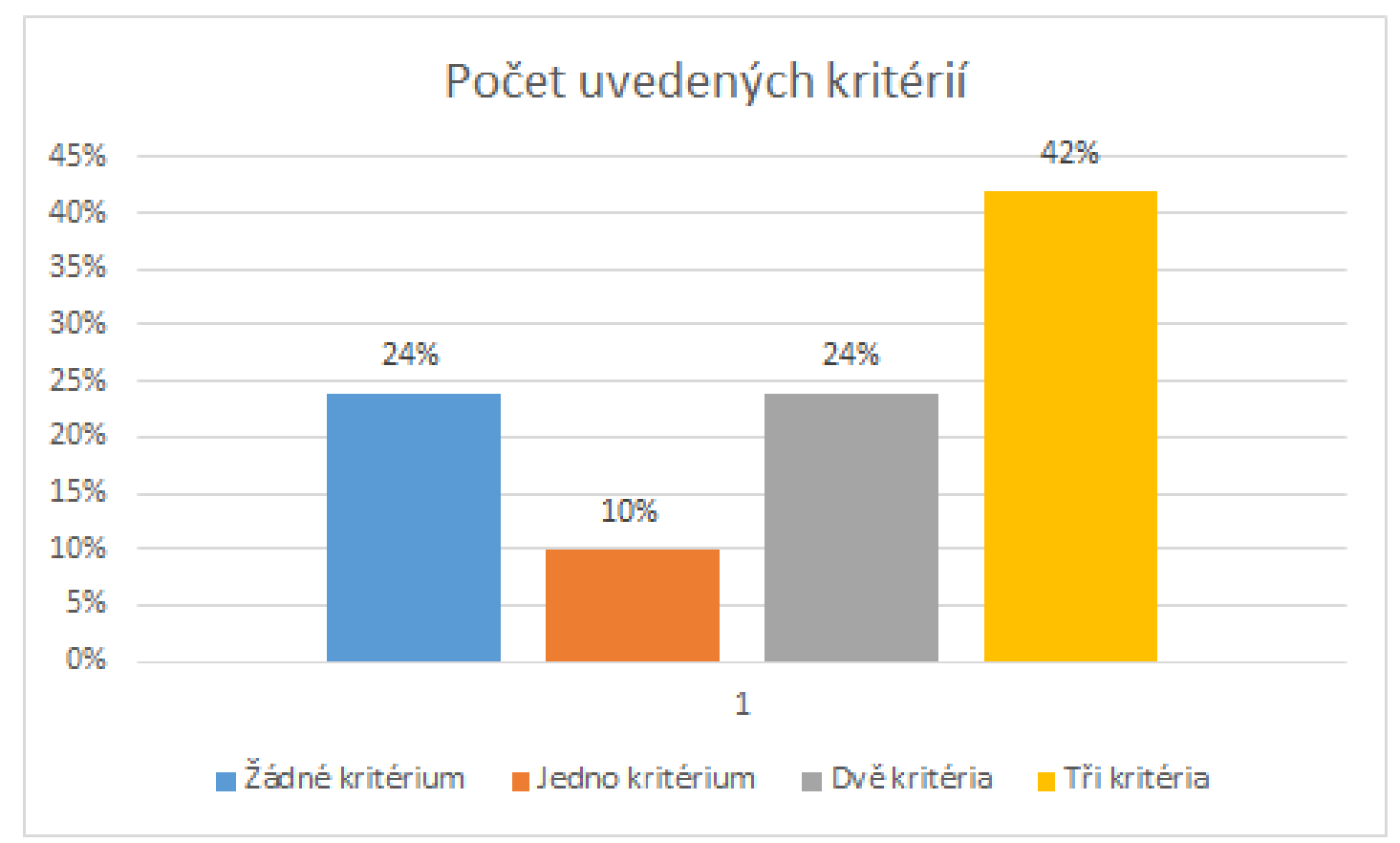

Obrázek 4. Graf znázorňující počet uvedených kritérií kvality, které byly studenti schopni uvést.

V grafu vidíme počet odpovědí studentů na otázku, v níž byli vyzváni, aby vyjmenovali 3 hlavní kritéria, podle kterých posuzují kvalitu zdroje. Většina studentů byla schopna uvést alespoň jedno či dvě kritéria, podle nichž se rozhodují, zda se jedná o kvalitní zdroj. Zarážející je však skutečnost, že více než pětina (24\%) studentů nebyla schopna uvést jediné kritérium. 


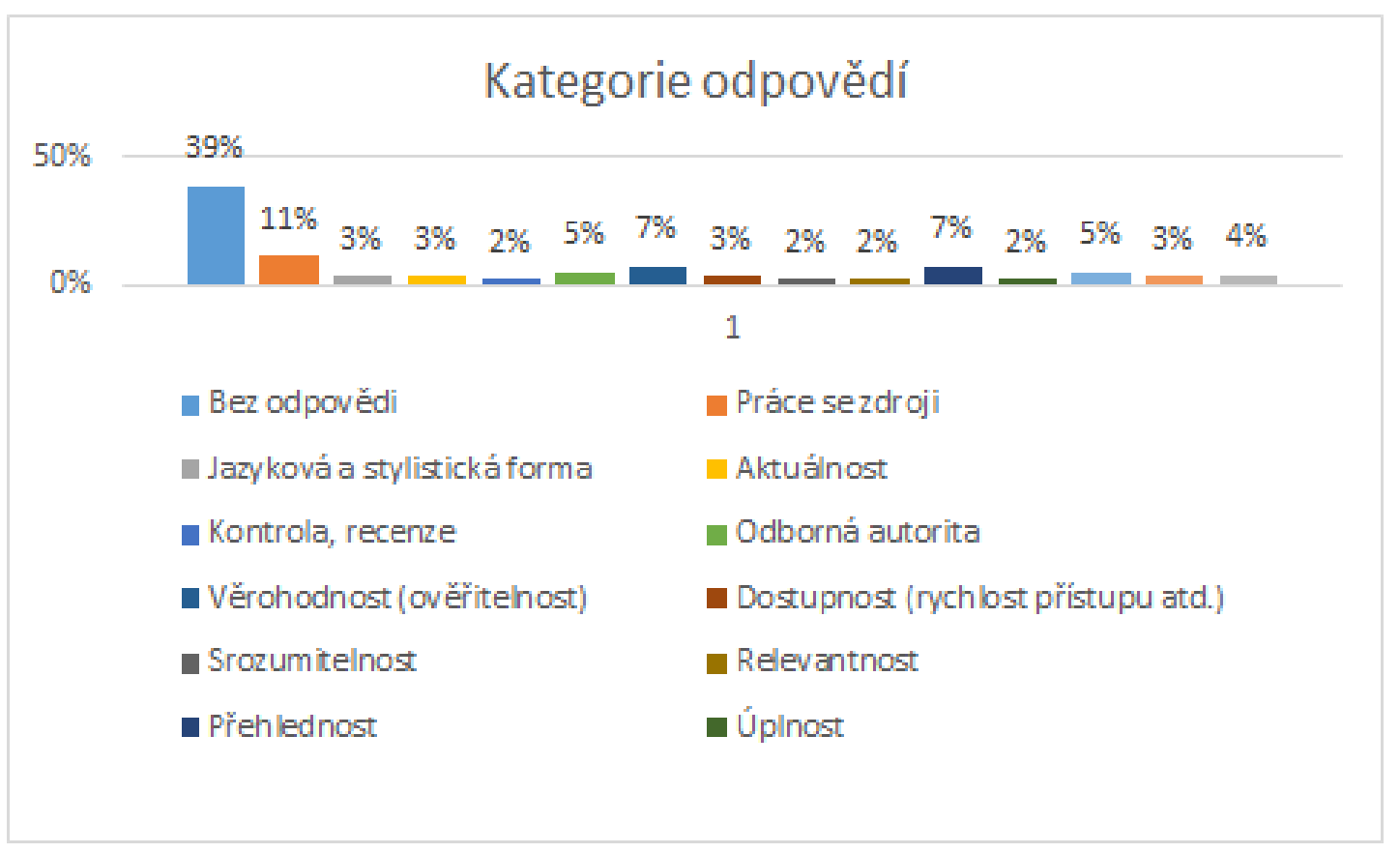

Obrázek 5. Graf znázorňující jednotlivé kategorie kritérií kvality.

Je patrné, že mezi nejčetnější odpovědi (kritéria) patřily ty, které se daly zařadit do kategorie „Práce se zdroji”. Studenti dále posuzují kvalitu zdroje podle toho, zda je přehledný, jestli je možné tvrzení ověřit a důležité kritérium pro ně představuje také to, zda je uvedena odborná autorita. Mưžeme proto říci, že pokud jsou studenti schopni kritérium uvést, často se jedná opravdu o užitečný indikátor, pomocí něhož se dá kvalita posoudit. Nicméně faktem zůstává, že řada studentů není schopna uvést ani tři kritéria a že nejčastější odpovědí byl proto prázdný řádek (Bez odpovědi).

Při kódování jsme stáli před možností využít některý ze stávajících rámců kritérií kvality (Kandari a kol., 2011) a zařazovat odpovědi studentů do jednotlivých položek, popř. vyřadit odpovědi, které nejsou relevantní pro tyto kategorie. Nakonec jsme se rozhodli sestavit kategorie vlastní, a to podle odpovědí studentů. Lépe to odpovídalo našemu záměru - tedy zjistit, jaké kritéria studenti využívají (tj. zda jsou schopni je sami pojmenovat). Nejdříve jsme přepsali všechny odpovědi studentů a na jejich základě jsme určili pracovní názvy kategorií, do nichž jsme odpovědi postupně řadili, přičemž jsme v průběhu vytvářeli kategorie nové, popř. modifikovali stávající, aby co nejlépe odpovídaly povaze odpovědí studentů.

- Do položky bez odpovědi jsme zařadili všechny prázdné či proškrtnuté řádky.

- Kategorie Práce se zdroji zahrnuje veškeré odpovědi, které se týkaly zdrojů či požadavků na uvedení zdroje. Studenti uváděli např. „citované zdroje”, ,,zdrojovanost”, ,,zdroj - odkud informace pochází" či ,,podle zdrojů".

- Kategorie Jazyková a stylistická forma obsahuje položky jako ,,jazyk”, , odborný jazyk", , ,textová odbornost", ,,jazyková terminologická správnost".

- Do Kategorie Aktuálnost jsou zařazena všechna kritéria, pro které je společným jmenovatelem aktualita informací, tedy např. „,čas-zastaralost”, ,datum”, , ,aktuálnost”, , ,dostatek nových informací". 
- V kategorii Kontrola, recenze jsou umístěna kritéria požadující recenzi či kontrolu zdroje třetí osobou. Žádná odpověd' ale nezmiňuje pojem recenzní řizení, můžeme tedy usuzovat, že recenzí studenti myslí např. recenzi uživateli, uváděli totiž položky jako: „,dobrá recenze", ,, podle recenzí", ,,recenze, hodnocení".

- V kategorii Odborná autorita jsou uvedena kritéria, pro které je klíčovou autoritou původce zdroje, jako je autor či instituce, tj.: ",Kdo to napsal - autor info", ,,podle autorů příspěvku", ,,vydané známou organizací", ,zaštitujíćí organizace”.

- Kategorie Věrohodnost $v$ sobě obsahuje odpovědi, pro které je klíčové, zda jsou informace věrohodně podloženy, tedy zda je možné je ověřit, např.: , Porovnání s tím, co sám vím nebo s jinými zdroji", "věrohodnost (jestli se shodnou i s jinými zdroji),, ",ověřování více zdrojü", „,důvěryhodnost".

- V kategorii Dostupnost jsou uváděna ta kritéria, pro které je charakteristické, zda je zdroj snadno a rychle dostupný jako: ,dostupnost na internetu", "rychlost prístupu", ",snadnost vyhledávání", ,jak rychle potřebnou informaci najdu".

- Kategorie Srozumitelnost zahrnuje odpovědi, které srozumitelnost jmenují prímo či je pro ně charakteristická: ,srozumitelnost", ,srozumitelnost textu", ,výstižnost' a srozumitelnost́ textu", , jak je zdroj srozumitelný, pochopitelný".

- Do kategorie Relevantnost jsme zařadili ty odpovědi, které kladly důraz na užitečnost a praktické využití informací, např. ",relevantnost informaci”, „,použití v praxi”, "týká se mého tématu, či ne", ,zda obsahuje opravdu informaci, kterou potřebuji".

- Kategorie Přehlednost obsahuje ty odpovědi, které požadují přehlednost zdroje: „,prehlednost", ,"přehlednost webu", ,kvalita zpracování a rozložení stránek", „,zřetelnost".

- Kategorie Úplnost obsahuje kritéria pro které je podstatné ucelenost zdroje jako: „,úplnost”, ,ucelenost”, ,,úplnost informací”, ,,celistvost informací", „obrazová dokumentace".

- V Kategorii Množství a obsah informací jsou uvedeny všechny odpovědi, pro něž je typické, že hodnotí kvalitu podle délky, rozsahu a obsahu informací: ,, rozsah zdroje”, „,množství informací, které zahrnují", ,,rozsah", ,,obsah", ,,obsáhlost textu”.

- Do kategorie Hodnocení uživateli, doporučení jsou zařazeny odpovědi, které kvalitu určují podle hodnocení zdroje či doporučení: ",hodnocení uživatelü", „Dám na doporučení spolužáků, vyučujících", „,doporučení".

- Kategorie Jiné $v$ sobě zahrnuje veškeré odpovědi, které nelze zařadit do výše uvedených kategorií a které se dají těžko zařadit do objektivních kritérií, jako je subjektivní dojem (bez popsání na čem je založený) - např.: „,moje zkušenost, intuice", , dle osobního přehledu", ,podle pocitu" či obecná kritéria, která samy o sobě nedávají smysl a nejsou prakticky odpovědí, na kterou směřovala otázka, např.: ,,kvalita”, ,,kvalita informací", ,,kvalita zdroje" atd.

V rámci studie jsme předložili zprávu o využívání OER studenty environmentálních oborů. Nezkoumali jsme ale pohledy pedagogů. Bylo by zajímavé zjistit, zda učitelé studenty k využívání OER vedou či mají nějaký vliv na přistup studentů k těmto zdrojům. Vyvstává totiž otázka, zda si studenti osvojují návyky sami, či jsou systematicky vedeni např. v rámci specializovaných kurzů, at' na vysokých školách, anebo ještě na školách středních. Můžeme se 
domnívat, že vzhledem $\mathrm{k}$ malé miře využívání termínu OER ve vysokoškolském diskurzu (Kapitulčinová a kol., 2015) nejsou tyto zdroje v rámci výuky ani systematicky probírány. Vnímání těchto zdrojů pedagogy a stav jejich zakomponování do výuky tedy může představovat námět pro další zkoumání.

Vzhledem ke specifiku našeho výzkumu nemůžeme naše výsledky př́mo srovnat $\mathrm{s}$ jinými studiemi zabývajícími se OER. Můžeme ale konstatovat, že podobně jako $v$ jiném výzkumu (Pow \& Li, 2015) má vnímání kvality informačního prostředí vliv na jeho využívání. To se nám ukazuje na př́kladu Wikipedie, kterou studenti považují za kvalitní zdroj a také ji využívají. Je patrné, že anglická Wikipedie je o poznání kvalitnější než její česká verze (vzhledem $\mathrm{k}$ množství přispěvatelů a editací). Toho jsou si pravděpodobně vědomi i studenti z výsledků je patrné, že anglická verze je hodnocena větším počtem studentů jako kvalitnější. Nehledě na tuto skutečnost je využívání české verze Wikipedie častější. Můžeme se domnívat, že jednak kvůli jazykové bariéře, jednak preferencí české verze ve vyhledávačích.

\section{Závěry}

Otevřené vzdělávací zdroje jsou důležitým fenoménem v oblasti vzdělávání, o čemž svědčí i jejich popularita mezi studenty. $z$ výsledků našeho výzkumu je patrné, že ani čeští studenti environmentálních oborů nejsou výjimkou a že tyto zdroje často využívají. Můžeme zároveň konstatovat, že pro část studentů je Wikipedie téměř synonymem OER, vzhledem $\mathrm{k}$ míre jejího využívání. Používají častěji její českou verzi, ačkoliv anglickou považují za kvalitnější. Polovina studentů má také zkušenost $s$ občasným využitím portálu s nelegálními studijními materiály - využívají ho zejména při plnění studijních povinností. Z toho se dá usuzovat na špatné návyky, které by jejich učitele nepotěšily. Ti by ale možná nebyli nadšeni ani využíváním Wikipedie, která $v$ akademickém prostředí často vzbuzuje spíše nedůvěru. Možná ale lepším způsobem, než je odrazování studentů od OER jako celku, je vydat se cestou aktivního př́stupu k němu a učit studenty, jak rozpoznat kvalitní zdroje. Bude se jim to hodit jak při studiu, tak v životě.

\section{Poděkování}

Tento výstup vznikl v rámci projektu Specifického vysokoškolského výzkumu 2017 260 471. Děkuji RNDr. Janě Dlouhé, Ph.D. za průběžnou konzultaci v průběhu výzkumu. Za konzultace při př́pravě metodické části děkuji PhDr. Marii Pospíšilové a doc. PhDr. Richardu Papíkovi, Ph.D. Při statistickém vyhodnocení mi byl nápomocný Matej Marek, MSc. Mgr. Dagmar Petiškové děkuji za korektury článku. 


\section{Literatura}

- Bawden, D., \& Robinson, L. (2009). The dark side of information: overload, anxiety and other paradoxes and pathologies. Journal of information science, 35(2), 180191. Retrieved from http://openaccess.city.ac. uk/3109/1/dark\%20side\%20of\%20information.pdf

- Bedford, D. (2010). Agnotology as a teaching tool: Learning climate science by studying misinformation. Journal of Geography, 109(4), 159-165. Retrieved from http://www.tandfonline.com/doi/abs/10.1080/00221341.2010.498121

- Belikov, O. M., \& Bodily, R. (2016). Incentives and barriers to OER adoption: A qualitative analysis of faculty perceptions. Open Praxis, 8(3), 235-246. Retrieved from http://www.openpraxis.org/ openprax/index. php/OpenPraxis/article/view/308/219

- Bessi, A., Coletto, M., Davidescu, G. A., Scala, A., Caldarelli, G., \& Quattrociocchi, W. (2015). Science vs conspiracy: Collective narratives in the age of misinformation. PloS one, 10(2), e0118093. Retrieved from http://journals. plos.org/plosone/article?id=10.1371/journal.pone.0118093

- Biddix, J. P., Chung, C. J., \& Park, H. W. (2011). Convenience or credibility? A study of college student online research behaviors. The Internet and Higher Education, 14(3), 175-182. Retrieved from https://www.researchgate.net/profile/Han_Park/publication/222036119 Convenienc e_or_credibility_A_study_of_college_student_online_research_behaviors/links/00463 536b910ab0212000000.pdf

- Bliss, T. J., \& Smith, M. (2017). A brief history of open educational resources. Open: The philosophy and practices that are revolutionizing education and science, 9-27.

- Bone, Elizabeth; McNichol, Sarah (2014). Students' views on learning methods and Open Educational Resources in higher education. The Higher Education Academy. York. Pages: 121 Retrieved from http://www.acasecretariat.be/index.php?id=29\&tx_smfacanewsletter_pi $1 \% 5 \mathrm{Bnl}$ _uid\%5D=115\&tx_s mfacanewsletter_pi $\% 5$ Buid $\% 5 \mathrm{D}=3955 \&$ tx_smfacanewsletter_pi $\% 5 \mathrm{BbackPid} \% 5 \mathrm{D}=$

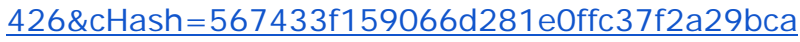

- Burton, V. T., \& Chadwick, S. A. (2000). Investigating the practices of student researchers: Patterns of use and criteria for use of Internet and library sources.Computers and Composition, 17(3), 309-328. Retrieved from http:// www.sciencedirect.com/science/article/pii/S8755461500000372

- Cordero, E. (2000). Misconceptions in Australian students' understanding of Ozone depletion. Critical Studies in Education, 41(2), 85-97. Retrieved from http://www. met.sjsu.edu/ cordero/ozone/MSIE_paper.pdf

- Dlouhá, J., Petiška, E., Dlouhý, J., \& Kapitulčinová, D. (2015). Opportunities and Risks of the Use of Open Education Resources in Environmental Disciplines at University Level in the Czech Republic: A Criteria for Assessing Quality. Envigogika, 10(4). Retrieved from https://www.envigogika.cuni.cz/index.php/Envigogika/article/view/503 
- Eldred, J. S. (2009). LABELING GMO-DERIVED FOOD INGREDIENTS: A RECIPE FOR MISINFORMATION. 27th Session of the Codex Committee on Food Labeling, Ottawa, Canada. Retrieved, 25. Retrieved from https://www.khlaw.com/files/3182_analysis.pdf

- Giles, J. (2005). Internet encyclopaedias go head to head (special report). Nature 438, 900-901.

- Graham, L., \& Metaxas, P. T. (2003). Of course it's true; I saw it on the Internet!: critical thinking in the Internet era. Communications of the ACM, 46(5), 70-75. Retrieved from http://faculty.chas.uni. edu/ wallingf/teaching/capstone/support/p70-graham.pdf

- Hewlett Foundation (2015). Open Educational Resources. Retrieved from http://www.hewlett.org/programs/education/open-educational-resources

- Hilton, J. (2016). Open educational resources and college textbook choices: a review of research on efficacy and perceptions. Educational Technology Research and Development, 1-18. Retrieved from http://link.springer.com/article/10.1007/s11423$\underline{016-9434-9}$

- Hu, E., Li, Y., Li, J., \& Huang, W. H. (2015). Open educational resources (OER) usage and barriers: a study from Zhejiang University, China. Educational Technology Research and Development, 63(6), 957-974. Retrieved from http://link.springer.com/article/10.1007/s11423-015-9398-1/fulltext.html

- Chen, X., Sin, S. C. J., Theng, Y. L., \& Lee, C. S. (2015). Why students share misinformation on social media: Motivation, gender, and study-level differences. The J ournal of Academic Librarianship, 41(5), 583-592. Retrieved from http://www.sciencedirect.com/science/article/pii/S0099133315001494

- Kandari, J. S., J ones, E. C., Nah, F. F., \& Bishu, R. R. (2011). Information quality on the world wide web: A framework to measure and its validation. In Proceedings of the 17th International Conference on Information Systems Analysis and Synthesis. Retrieved from http://www.iiis.org/CDs2011/CD2011IMC/ISAS_2011/PapersPdf/UA623FD.pdf

- Kapitulčinová, D., Spustová, K., Nemcová, M., Petiška, E., Dlouhá, J. (2015). Analýza využívání termínu Open Educational Resources na českých vysokých školách v mezinárodním kontextu. AULA 23 (2), 29-48. Retrieved from http://www.csvs.cz/aula/201502.php

- Klein, B. D. (2002). Internet data quality: Perceptions of graduate and undergraduate business students. J ournal of Business and Management, 8(4), 425. Retrieved from http://search.proquest.com/docview/211510185?pqorigsite $=$ gscholar

- Novotný, Jiří. 2010. Ekologové zpožd'ují dokončení dálnice D8. Novinky.cz. Retrieved from https://www.novinky.cz/domaci/191690-ekologove-zpozduji-dokoncenidalnice-d8.html

- Pow, J., \& Li, S. C. (2015). The effect of students' perceptions of Internet information quality on their use of Internet information in inquiry-based learning. Australasian J ournal of Educational Technology, 31(4), 439-457. Retrieved from https://ajet.org.au/index.php/AJET/article/view/1936/1296 
- Roeder, I., Severengiz, M., Stark, R., \& Seliger, G. (2017). Open educational resources as a driver for manufacturing-related education for learning of sustainable development. Procedia Manufacturing, 8, 81-88. Retrieved from http://www.sciencedirect.com/science/article/pii/S2351978917300148

- TES Global. (2016). "Three in Four U.S. Teachers Say Open Educational Resources Are Used More Often Than Textbooks." Retrieved from https://www.tesglobal.com/teachertech2

- Tjoa, A. M., \& Tjoa, S. (2016). The Role of ICT to Achieve the UN Sustainable Development Goals (SDG). In IFIP World I nformation Technology Forum (pp. 3-13). Springer International Publishing. Retrieved from https://link.springer.com/chapter/10.1007/978-3-319-44447-5_1

- $\quad$ van der Linden, S., Leiserowitz, A., Rosenthal, S., \& Maibach, E. (2017). Inoculating the public against misinformation about climate change. Global Challenges, 1(2). Retrieved from http://onlinelibrary.wiley.com/doi/10.1002/gch2.201600008/full

- Warwick, C., Rimmer, J., Blandford, A., Gow, J., \& Buchanan, G. (2009). Cognitive economy and satisficing in information seeking: A longitudinal study of undergraduate information behavior. Journal of the American Society for Information Science and Technology, 60(12), 2402-2415. Retrieved from http://dro.dur.ac.uk/13497/1/13497.pdf

- Wei, L., \& Zhang, M. (2008). The impacts of Internet knowledge on college students' intention to continue to use the Internet. Information Research, 13(3), 2. Retrieved from http://www. informationr. net/ir/13-3/paper348.html

- Wiley, D., Bliss, T. J., \& McEwen, M. (2014). Open Educational Resources: a review of the literature. In Handbook of research on educational communications and technology (pp. 781-789). Springer New York.

- Wineburg, S., McGrew, S., Breakstone, J., \& Ortega, T. (2016). Evaluating Information: The Cornerstone of Civic Online Reasoning. Retrieved from https://purl.stanford. edu/fv751yt5934 


\section{Př́lohy}

\section{Př́loha 1}

Tabulka z výzkumů zaměřujících se na české OER využitelné pro oblast životního prostředí (Dlouhá a kol., 2015)

\begin{tabular}{|c|c|c|c|c|c|c|c|c|c|c|}
\hline \multicolumn{2}{|c|}{ Kategorie / Kódy } & název zdroje & $\begin{array}{l}\text { copy- } \\
\text { right }\end{array}$ & $\begin{array}{c}\text { autor- } \\
\text { stvi }\end{array}$ & $\begin{array}{l}\text { datum } \\
\text { publik. }\end{array}$ & $\begin{array}{l}\text { rádné } \\
\text { citace }\end{array}$ & recenze & \begin{tabular}{|c|} 
vyzna- \\
čení kva- \\
lity
\end{tabular} & $\begin{array}{c}\text { korektni } \\
\text { po- } \\
\text { stup*** }\end{array}$ & $\begin{array}{l}\text { „nabídka“ pro VŠ výuku a rozvijené kompetence } \\
\text { z hlediska EV a VUR }\end{array}$ \\
\hline \multirow{3}{*}{\multicolumn{2}{|c|}{$\begin{array}{l}\text { částečně uzavřené } \\
\text { prostředi (v̌̌echny či } \\
\text { některé funkce jen } \\
\text { pro přılíšené, nebo } \\
\text { otevřené omylem) }\end{array}$}} & $\frac{\text { Informačni systém }}{\mathrm{MU}}$ & $\mathrm{NE}$ & 0 & ANO & 0 & $\mathrm{NE}$ & NE & ANO & Snadná dostupnost - materiály z oblasti ekologie a Žp \\
\hline & & $\frac{\underline{\text { Studijni opory VŠB- }}}{\underline{\text { TU }}}$ & ANO & 0 & 0 & 0 & 0 & 0 & 0 & $\begin{array}{c}\text { Snadná dostupnost - materiály katedry ochrany ŽP v } \\
\text { prủmyslu }\end{array}$ \\
\hline & & Khanova škola & $\mathrm{NE}$ & 0 & ANO & 0 & ANO & NE & ANO & $\begin{array}{l}\text { Atraktlvni videa - pro rychlokurz základů blologle a eko- } \\
\text { logie }\end{array}$ \\
\hline \multirow{3}{*}{\multicolumn{2}{|c|}{$\begin{array}{l}\text { prostředi otevřené } \\
\text { pro čteni }\end{array}$}} & $\underline{\underline{E n v i r o n m e n t a l i s t i k a ~}}$ & ANO & $\mathrm{NE}$ & $\mathrm{NE}$ & NE & $\mathrm{NE}$ & $\mathrm{NE}$ & 0 & $\begin{array}{c}\text { Všechny piliř̌e udržitelnosti v globálním i lokálním po- } \\
\text { hledu - stručnost, přehlednost, utříděná témata }\end{array}$ \\
\hline & & $\frac{\text { Studovna Elportálu }}{\text { MUNI }}$ & ANO & ANO & ANO & 0 & 0 & ANO & ANO & $\begin{array}{c}\begin{array}{c}\text { Fulltextové učebnice - vysoká kvalita, dostupnost, spo- } \\
\text { lehlivost, oborové členěni (mimo ŽP a UR) }\end{array} \\
\end{array}$ \\
\hline & & $\frac{\text { Portál pro cestovní }}{\text { ruch UHK }}$ & 0 & 0 & ANO & 0 & $\mathrm{NE}$ & NE & 0 & $\begin{array}{c}\text { Úložiště materiálů - různorodost (obsah, forma), kolisa- } \\
\text { jicí kvalita, často mimo ŽP a UR }\end{array}$ \\
\hline \multirow{3}{*}{$\begin{array}{l}\text { otevřené } \\
\text { interak- } \\
\text { tivni* }\end{array}$} & $\begin{array}{c}\text { testy a } \\
\text { kvizy }\end{array}$ & Prírodné javy & ANO & 0 & 0 & 0 & ANO & 0 & 0 & $\begin{array}{c}\text { Interaktivni portál, přehlednost, testováni znalosti (pří- } \\
\text { prava na zkoušky) }\end{array}$ \\
\hline & \multirow{2}{*}{$\begin{array}{c}\text { dis- } \\
\text { kusni } \\
\text { prostor } \\
* *\end{array}$} & INFO lu2 & ANO & 0 & NE & 0 & NE & NE & $\mathrm{NE}$ & $\begin{array}{c}\text { Úložišťě pro studenty (skripta ŽP, taháky...) - nelegální } \\
\text { zdroje a postupy }\end{array}$ \\
\hline & & Technika na ČZU & NE & 0 & ANO & 0 & $\mathrm{NE}$ & NE & $\mathrm{NE}$ & $\begin{array}{l}\text { Zdroje pro studenty oboru - spravuje absolvent, využívá } \\
\text { k širireni reklam }\end{array}$ \\
\hline \multirow{3}{*}{\multicolumn{2}{|c|}{$\begin{array}{l}\text { prostředi otevřené } \\
\text { pro úpravy }\end{array}$}} & Enviwiki & ANO & ANO & ANO & 0 & 0 & 0 & 0 & $\begin{array}{c}\text { Multidisciplinárni povaha textů umožňuje skloubit po- } \\
\text { znatky z rủzných oblasti ŽP a UR a propojit aktéry a zna- } \\
\text { losti (použiváni hyperlinkủ, kategorie, atd). }\end{array}$ \\
\hline & & Wikiskripta & ANO & ANO & ANO & ANO & ANO & ANO & ANO & $\begin{array}{l}\text { Exemplárni príklad dělby práce ve Wiki - zapojeni + kva- } \\
\text { lita (jen několik článkủ (týkajicich se ŽP a zdravi) }\end{array}$ \\
\hline & & Wikipedie & ANO & ANO & ANO & ANO & ANO & 0 & 0 & $\begin{array}{l}\text { Mezioborové propojeni témat, zdůrazněni souvislostí, } \\
\text { možnost propagace témat (odkazy z jiných stránek) }\end{array}$ \\
\hline \multirow{3}{*}{\multicolumn{2}{|c|}{$\begin{array}{l}\text { primárně komerční } \\
\text { stránky (mira otevře- } \\
\text { nosti nehraje roli) }\end{array}$}} & primat.cz & ANO & 0 & ANO & 0 & NE & NE & NE & $\begin{array}{l}\text { Materiály nelegální (otázky ke zkoušce atd.), různá kva- } \\
\text { lita, komerčni cil }\end{array}$ \\
\hline & & veiska.cz & ANO & 0 & ANO & 0 & NE & NE & NE & $\begin{array}{c}\text { Materiály pro všechny VŠ - nekorektni sdíleni (otázky } \\
\text { k testưm atd.) }\end{array}$ \\
\hline & & Unium & ANO & ANO & ANO & 0 & $\mathrm{NE}$ & $\mathrm{NE}$ & $\mathrm{NE}$ & $\begin{array}{c}\text { Materiály pro všechny VŠ - nekorektni sdileni (nabídka } \\
\text { vypracováni praci) }\end{array}$ \\
\hline
\end{tabular}

*neumožňujicí úpravy existujicích textů $\mid{ }^{* *}$ možnost přidávat materiály $\quad$ *** Užiti zdroje nevede k plagiátorství; práci s nekvalitními zdroji; nekritickému prístupu,...

Tabulka 4. Výsledek kódování vybraných OER zdrojů podle kritérií kvality. „Hodnoty” kódů (ANO, NE, 0) představují jejich zjednodušený kvalitativní popis: ANO znamená, že dané kritérium bylo víceméně naplněno, NE pak znači opak (většinou dané kritérium naplněno nebylo). „Hodnota" 0 byla užita v připadech, že nebylo možné z různých důvodů přiřadit zdroji předchozi dvě "hodnoty” (podrobnosti viz diskuze). 


\section{Př́loha 2}

V prvním řádku Frekvence využívání ohodnot jak často využíváš daný zdroj při studiu ŽP: 1=denně; 2=týdně; 3=měsíčně; 4=méně často; $5=$ =nevyužil jsem, vím, že existuje; 6=neznám

Ve druhém řádku Hodnocení kvality ohodnot' jak Ti přijde daný zdroj kvalitní ke studiu ŽP: 1=rozhodně kvalitní; 2=spíše kvalitní; 3=nevím; 4=spíše nekvalitní; 5=rozhodně nekvalitní

Ve třetím řádku uved' Účely využívání uved' všechny účely pro které zdroj využíváš při studiu ŽP: 1=hlavní zdroj; 2=doplněk a sekundární zdroj; 3=rozcestník k dalším zdrojům; 4=příprava na zkoušky/psaní atestačních prací; 5=studium nad rámec sstudij. požadavků

Pokud znáš další OER ke studiu ŽP, uved' je do prázdných míst (Název zdroje) a také ohodnot':

\begin{tabular}{|l|l|l|l|l|l|l|l|l|}
\hline $\begin{array}{l}\text { Název } \\
\text { zdroje }\end{array}$ & $\begin{array}{l}\text { Environm } \\
\text { entalistika }\end{array}$ & Enviwiki & $\begin{array}{l}\text { Wikipedis } \\
\text { (česká) }\end{array}$ & $\begin{array}{l}\text { Wikipedie } \\
\text { (anglická) }\end{array}$ & primat.cz & & & \\
\hline $\begin{array}{l}\text { Frekvence } \\
\text { Využívání }\end{array}$ & & & & & & & & \\
\hline $\begin{array}{l}\text { Hodnocení } \\
\text { kvality }\end{array}$ & & & & & & & & \\
\hline $\begin{array}{l}\text { Účely } \\
\text { využívání }\end{array}$ & & & & & & & & \\
\hline
\end{tabular}

5) Můžeš napsat v bodech 3 hlavní kritéria, podle kterých posuzuješ kvalitu OER? Každé kritérium napiš na jeden řádek, pokud nevíš, nechej prázdný řádek.

1.

2.

3. 


\section{Př́loha 3}

\section{Frekvence využívání}

\begin{tabular}{|c|c|c|c|c|c|c|c|}
\hline & 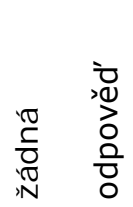 & 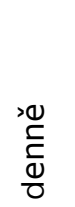 & 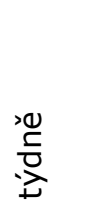 & 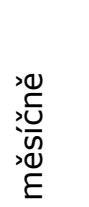 & 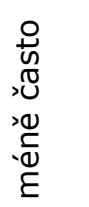 & 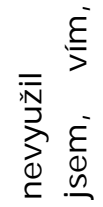 & $\begin{array}{l}\stackrel{E}{\mathbb{N}} \\
\stackrel{\mathbb{N}}{\mathbb{N}} \\
\stackrel{\mathbb{N}}{\simeq}\end{array}$ \\
\hline Environmentalistika & $4 \%$ & $1 \%$ & $6 \%$ & $8 \%$ & $6 \%$ & $18 \%$ & $57 \%$ \\
\hline Enviwiki & $3 \%$ & $1 \%$ & $6 \%$ & $16 \%$ & $19 \%$ & $23 \%$ & $31 \%$ \\
\hline Wikipedie (česká) & $1 \%$ & $9 \%$ & $45 \%$ & $26 \%$ & $15 \%$ & $3 \%$ & $0 \%$ \\
\hline Wikipedie (anglická) & $3 \%$ & $7 \%$ & $28 \%$ & $29 \%$ & $21 \%$ & $11 \%$ & $1 \%$ \\
\hline primat.cz & $3 \%$ & $0 \%$ & $5 \%$ & $14 \%$ & $31 \%$ & $39 \%$ & $7 \%$ \\
\hline
\end{tabular}

\section{Účely využívání}

\begin{tabular}{|c|c|c|c|c|c|c|}
\hline & 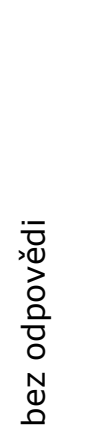 & 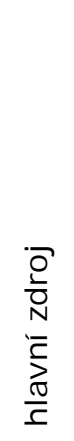 & 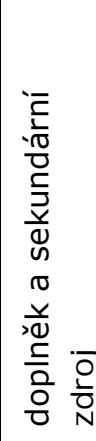 & 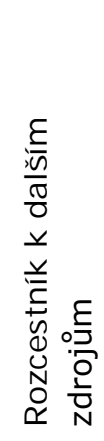 & 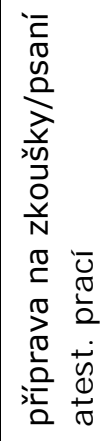 & 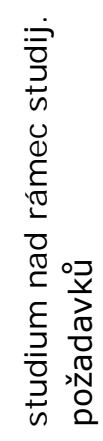 \\
\hline Environmentalistika & $55 \%$ & $4 \%$ & $18 \%$ & $13 \%$ & $2 \%$ & $9 \%$ \\
\hline Enviwiki & $41 \%$ & $3 \%$ & $25 \%$ & $19 \%$ & $5 \%$ & $6 \%$ \\
\hline Wikipedie (česká) & $3 \%$ & $8 \%$ & $38 \%$ & $40 \%$ & $7 \%$ & $5 \%$ \\
\hline Wikipedie (anglická) & $6 \%$ & $6 \%$ & $42 \%$ & $28 \%$ & $9 \%$ & $9 \%$ \\
\hline primat.cz & $35 \%$ & $1 \%$ & $22 \%$ & $12 \%$ & $25 \%$ & $5 \%$ \\
\hline
\end{tabular}




\section{Hodnocení kvality}

\begin{tabular}{|c|c|c|c|c|c|c|}
\hline & 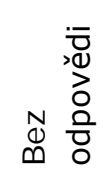 & 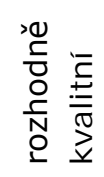 & 竞焉 & 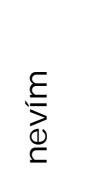 & 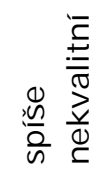 & 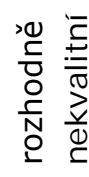 \\
\hline Environmentalistika & $17 \%$ & $6 \%$ & $14 \%$ & $63 \%$ & $0 \%$ & $0 \%$ \\
\hline Enviwiki & $11 \%$ & $7 \%$ & $27 \%$ & $52 \%$ & $3 \%$ & $0 \%$ \\
\hline Wikipedie (česká) & $2 \%$ & $3 \%$ & $48 \%$ & $12 \%$ & $33 \%$ & $3 \%$ \\
\hline Wikipedie (anglická) & $3 \%$ & $15 \%$ & $56 \%$ & $19 \%$ & $8 \%$ & $0 \%$ \\
\hline primat.cz & $11 \%$ & $1 \%$ & $22 \%$ & $12 \%$ & $25 \%$ & $5 \%$ \\
\hline
\end{tabular}

\section{Mgr. Eduard Petiška}

eduard.petiska@gmail.com

Doktorand

Univerzita Karlova

Centrum pro otázky životního prostředí

J osé Martíno 2

http://czp.cuni.cz 